\title{
Metode term frequency - invers document frequency pada mekanisme pencarian judul skripsi
}

\author{
Meiga Ayu Ariyanti Nur Fitroh ${ }^{1}$, Aji Prasetya Wibawa ${ }^{2}$, Utomo Pujianto ${ }^{3}$ \\ 1. Universitas Negeri Malang, Indonesia | meigameisha@gmail.com \\ 2. Universitas Negeri Malang, Indonesia | aji.prasetya.ft@um.ac.id \\ 3. Universitas Negeri Malang, Indonesia | utomo.pujianto.ft@um.ac.id
}

\begin{abstract}
Abstrak
Tujuan penelitian dan pengembangan ini adalah (1) merancang dan membangun mekanisme pencarian dengan metode TF-IDF sebagai salah satu fitur yang ada pada SISINTA, (2) menguji akurasi, presisi, dan sensitifitas metode TF-IDF, dan (3) menguji fungsionalitas mekanisme pencarian dengan metode TF-IDF. Hasil penelitian dan pengembangan ini berupa fitur mekanisme pencarian judul skripsi dengan metode term frequency dan invers document frequency (TF-IDF). Fitur tersebut dapat menampilkan hasil pencarian judul skripsi yang relevan sesuai dengan kata kunci pencarian oleh pengguna. Berdasarkan hasil pengujian white-box yang dilakukan dengan pengujian akurasi, presisi dan sensitifitas didapatkan persentase yang sama yaitu sebesar 92\%. Hasil tersebut termasuk kategori sempurna. Hasil uji coba kepada pengguna yang merupakan pengujian black-box menghasilkan keberhasilan fungsionalitas sebesar $100 \%$. Berdasarkan hasil rata-rata pengujian white-box dan black-box diperoleh persentase sebesar 96\%, sehingga dapat disimpulkan metode TF-IDF dalam mekanisme pencarian judul skripsi SISINTA ini sangat valid dan sangat layak untuk digunakan.
\end{abstract}

Kata Kunci

Pencarian, Judul, Skripsi, Term Frequency - Invers Document Frequency (Tf-Idf) 


\section{TEKNO Jurnal Teknologi, Elektro, dan Kejuruan}

http://journal2.um.ac.id/index.php/tekno | ISSN 1693-8739

\section{Pendahuluan}

Skripsi adalah suatu karangan atau karya ilmiah sebagai persyaratan kelulusan akademis dari pendidikan strata satu (Pusat Bahasa Depdiknas, 2002). Setiap mahasiswa yang ingin mendapatkan gelar strata satu diharuskan menyusun skripsi. Pada umumnya, tahapan penyusunan skripsi meliputi pengajuan judul, keputusan penerimaan judul, penentuan dosen pembimbing, konsultasi, seminar proposal skripsi, bimbingan, dan sidang skripsi.

Tahap awal yang harus dilakukan mahasiswa dalam pengajuan judul skripsi adalah mahasiswa harus menentukan topik dan menyusun struktur kalimat judul yang tepat. Penentuan topik dan penyusunan judul skripsi memerlukan referensi penelitian terdahulu yakni berasal dari judul judul skripsi yang sudah diterima sebelumnya (Waspodo, 2015). Referensi dari penelitian sebelumnya berguna untuk menghindari penggunaan topik yang sudah banyak dikembangkan dan pembuatan judul skripsi yang sama persis namun hanya berbeda lokasi penelitiannya (Akbar,2013). Dengan adanya referensi judul skripsi terdahulu mahasiswa mampu memperkirakan topik mana yang patut diteliti atau dikembangkan, serta penyusunan struktur kalimat judul sehingga dapat lebih efisien untuk meningkatkan persentase judul skripsi mahasiswa tersebut diterima.

Dengan adanya kebutuhan pencarian referensi judul-judul skripsi terdahulu maka diperlukan mekanisme pencarian judul skripsi sebagai salah satu fitur yang digunakan dalam mengembangkan sistem infromasi skripsi dan tugas akhir (SISINTA) di Jurusan Teknik Elektro Universitas Negeri Malang. Pengembangan fitur pencarian judul dalam SISINTA akan memudahkan mahasiswa dalam mencari judul secara otomatis tanpa perlu melakukan pencarian secara manual atau pencarian satu persatu judul skripsi di perpustakaan.

Pengembangan fitur mekanisme pencarian judul memerlukan suatu metode untuk membuat suatu pencarian yang efektif dan efisien (Ardiansah, 2016) (Mandala dkk, 2002) Penentuan metode yang tepat berkaitan dengan pemilihan atau penemuan kembali informasi yang tidak mungkin dilakukan secara manual karena kumpulan informasi yang sangat besar dan terus bertambah besar (Zafikri, 2008). Pemilihan mekanisme pencarian yang tepat akan meningkatkan keefektifitasan sistem informasi yang dikembangkan (Al Fatta, 2007).

Salah satu mekanisme pencarian yang dapat digunakan adalah metode term frequency dan invers document frequency (TF-IDF) (Satria, 2015) (Nurjannah dkk, 2013). Dalam artikel yang berjudul "Penerapan Algoritma Term Frequency-Inverse Document Frequency (TF-IDF) untuk Text Mining" telah dilakukan uji coba untuk mengetahui hasil dari penerapan TF-IDF (Wahono, 2006). Hasil dari penelitian menunjukan bahwa, penerapkan algoritma term frequency inversedocument frequency untuk text mining sangat membantu pengguna untuk mendapatkan informasi pada kumpulan dokumen (Nurhannah dkk, 2013). Dalam artikel lain yang berjudul "Sistem Temu Kembali Dokumen Teks dengan Pembobotan TF-IDF dan LCS" (Fauzi, 2014) dilakukan pengujian kelayakan untuk mengetahui kemampuan sistem. Pengujian dilakukan terhadap 140 buah dokumen berita berbahasa Indonesia yang tergolong dalam 11 buah kategori. Untuk mengetahui kemampuan sistem yang diusulkan dilakukan perhitungan nilai 


\section{TEKNO Jurnal Teknologi, Elektro, dan Kejuruan}

http://journal2.um.ac.id/index.php/tekno | ISSN 1693-8739

presisi dan recall terhadap 57 kali uji coba dengan query yang berbeda (Powers, 2011). Nilai persentase yang didapatkan dari hasil pengujian presisi dan recall sistem sebesar 30,36\% dan 96,84\% (Saadah dkk, 2013). Jika diperbandingan dengan metode lain, metode TF-IDF yang menerapkan cosine similarity di dalamnya lebih unggul (Pujianto, 2013). Hal ini dibuktikan dari artikel yang berjudul "Perbandingan Metode Cosine Similarity dengan Metode Jaccard Similarity pada Aplikasi Pencarian Terjemah AI-Quran dalam Bahasa Indonesia”. Dalam artikel ini metode cosine, jaccard dan k-nearest neighbor (K-NN) digunakan pada proses klasifikasi dokumen teks dengan hasil akhir dari percobaan 33 kali menggunakan key yang berbeda dengan total 6326 dokumen sehingga didapatkan metode cosine yang nilai kemiripannya tertinggi yaitu $41 \%$ dari metode jaccard 19\% dan k-nearest neighbor (K-NN) 40\% (Nurdiana dkk, 2016). Berdasarkan hasil observasi dari penelitian sudah pernah dilakukan tersebut, maka dipilihlah metode TF-IDF untuk mengembangkan fitur pencarian judul skripsi pada SISINTA.

TF-IDF pada sistem temu kembali informasi atau information retrieval system (Jogiyanto, 2005), merupakan metode penghitungan bobot setiap kata yang paling umum digunakan (Mutaqin, 2016). Metode ini merupakan algoritma yang melakukan penggabungan dua metode yaitu konsep frekuensi kemunculan term dalam sebuah dokumen dan inverse frekuensi dokumen yang mengandung kata tersebut, sehingga proporsi jumlah dokumen yang ditemukan kembali dan dianggap relevan dengan query akan meningkatkan (Amin, 2011; Schniter, 2003). Dengan menggunakan metode ini pencarian akan lebih efisien, mudah dan memiliki hasil yang akurat (Pendit, 2008).

Berdasarkan uraian di atas, penulis bermaksud melakukan penelitian yang berjudul: Metode Term Frequency dan Invers Document Frequency (TF-IDF) pada Mekanisme Pencarian Judul Skripsi Dalam Sistem Informasi Skripsi dan Tugas Akhir Di Jurusan Teknik Elektro Universitas Negeri Malang.

\section{Metode}

Model pengembangan metode term frequency dan invers document frequency (TF-IDF) pada mekanisme pencarian judul skripsi dalam sistem informasi skripsi dan tugas akhir menggunakan model prototype. Model prototype adalah model pengembangan yang menggambarkan dasar hal-hal penting dari sistem informasi yang akan dibuat. Pengguna memberikan masukan terhadapat kebutuhan sistem, kemudian dilakukan perbaikan sesuai dengan masukan pengguna sehingga lebih reliabel (Lancaster,1979). Model ini cocok digunakan untuk membangun sebuah perangkat yang akan dikembangkan kembali.

Prosedur pengembangan dari model prototype mempunyai beberapa tahapan sebagai berikut: (1) communication (komunikasi), (2) quick plan - modeling quick design (perencanaan secara cepat - pemodelan secara cepat), (3) construction of prototype (pembentukan prototype), dan (4) deployment delivery and feedback (penyerahan dan umpan balik). Ilustrasi model prototipe tersaji pada Gambar 1. 


\section{TEKNO Jurnal Teknologi, Elektro, dan Kejuruan}

http://journal2.um.ac.id/index.php/tekno | ISSN 1693-8739

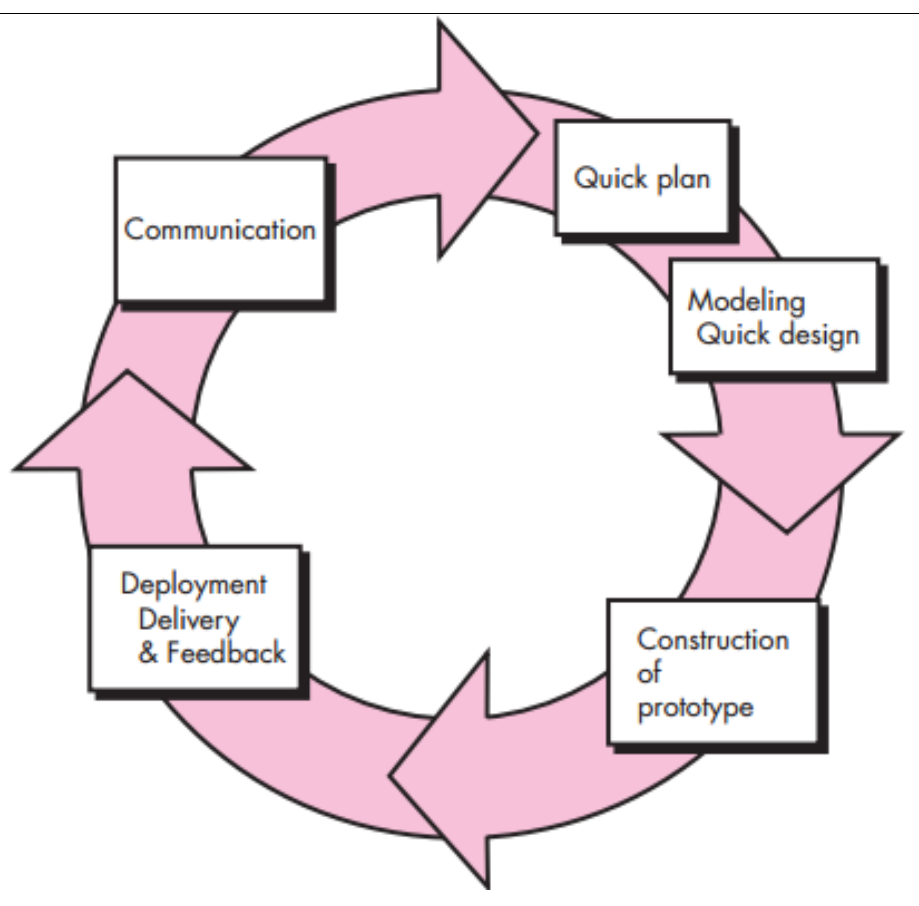

Gambar 1. Ilustrasi Model Prototype (Sumber: Pressman, 2010)

1. Communication (Komunikasi)

Komunikasi awal ini membahas tentang alur sistem yang akan dikembangkan, fitur-fitur yang dibutuhkan, metode yang diterapkan dan database yang digunakan. Tahap komunikasi ini menghasilkan alur SISINTA yang sesuai dengan aturan baru tahapan skripsi yang berlaku di Jurusan Teknik Elektro Universitas Negeri Malang. Dari alur SISINTA yang baru maka diperlukan pengembangan fitur-fitur lain untuk mendukung dan memperbaiki SISINTA (Nasution, 2001).

Salah satu fitur yang dikembangkan adalah fitur halaman katalog judul. Halaman katalog judul ini memberikan fasilitas pencarian judul skripsi. Untuk dapat mengakses fitur katalog judul, pengguna harus login terlebih dahulu ke SISINTA. Kemudian akan muncul halaman utama dari SISINTA. Selanjutnya pengguna dapat mengakses fitur katalog judul untuk melakukan pencarian judul skripsi. Setelah pengguna memasukkan kata kunci akan muncul hasil pencarian sesuai dengan kata kunci pengguna. Alur penggunaan fitur katalog judul pada SISINTA digambarkan pada Gambar 2. 


\section{TEKNO Jumal Teknologi, Eektro, dan kejivuan}

http://journal2.um.ac.id/index.php/tekno | ISSN 1693-8739

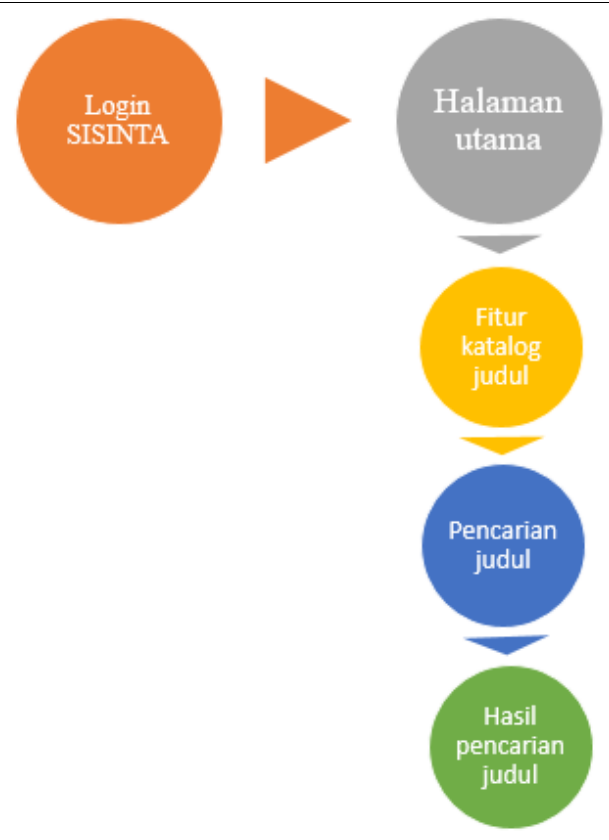

Gambar 2. Alur Penggunaan Fitur Katalog Judul

2. Quick Plan - Modeling Quick Design (Perencanaan Secara Cepat - Pemodelan Secara Cepat)

Tahap perencanaan/pemodelan secara cepat bertujuan untuk membuat Setelah melalui tahap komunikasi maka didapatkan apa yang dibutuhkan untuk mengembangkan SISINTA yakni dengan penambahan fitur pencarian judul. Tahap selanjutnya adalah perencanaan secara cepat. Pada tahap perencanaan yang dilakukan adalah membuat desain awal sistem. Terdapat tiga rancangan sistem, meliputi; (a) pemodelan proses, (b) pemodelan data, dan (c) desain antar muka.

Tahap pemodelan proses adalah tahapan untuk merancang Data Flow Diagram (DFD) yang menggambarkan bagaimana sistem berjalan sesuai dengan pada tahap komunikasi sebelumnya. Pembuatan DFD dimulai dari diagram konteks dan DFD Level 1. Diagram konteks disajikan pada Gambar 3 dan DFD Level 1 disajika pada Gambar 4 berikut.

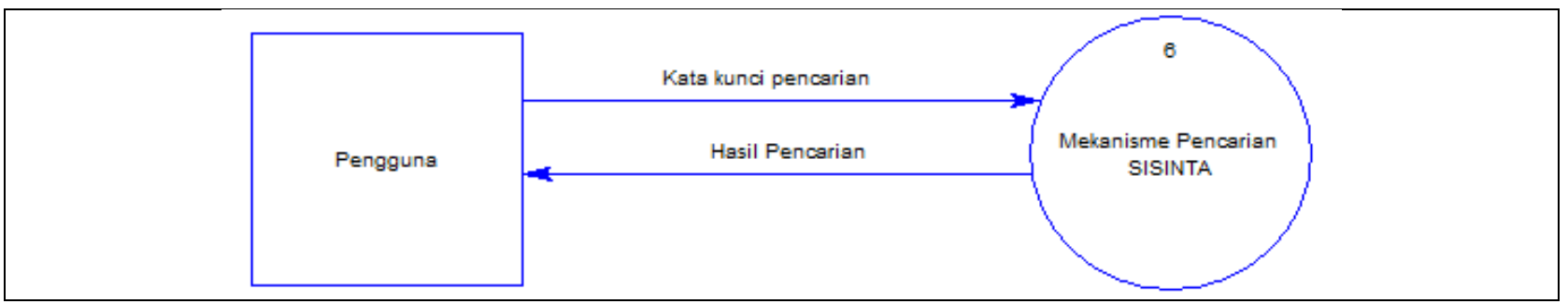

Gambar 3. Diagram Konteks Fitur Mekanisme Pencarian Judul SISINTA 


\section{TEKNO Junal Teknologi, Ekekro, dan Kejuvran}

http://journal2.um.ac.id/index.php/tekno | ISSN 1693-8739

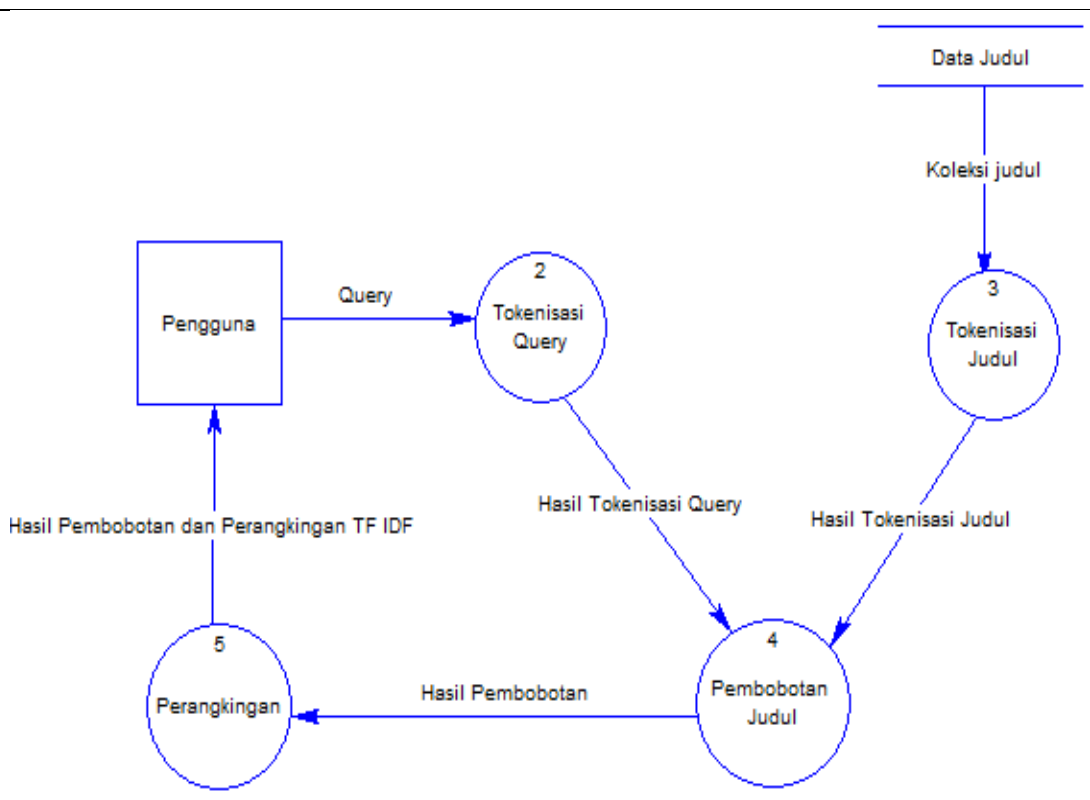

Gambar 4. DFD Level 1 Fitur Mekanisme Pencarian Judul SISINTA

Pemodelan data menggambarkan data yang dipakai pada suatu sistem. Dalam pemodelan data digunakan Entity Relationship Diagram (ERD) untuk menunjukkan bagaimana data dan informasi akan disimpan serta hubungan antar entitasnya. ERD dari fitur mekanisme pencarian judul SISINTA disajikan pada Gambar 5 berikut.

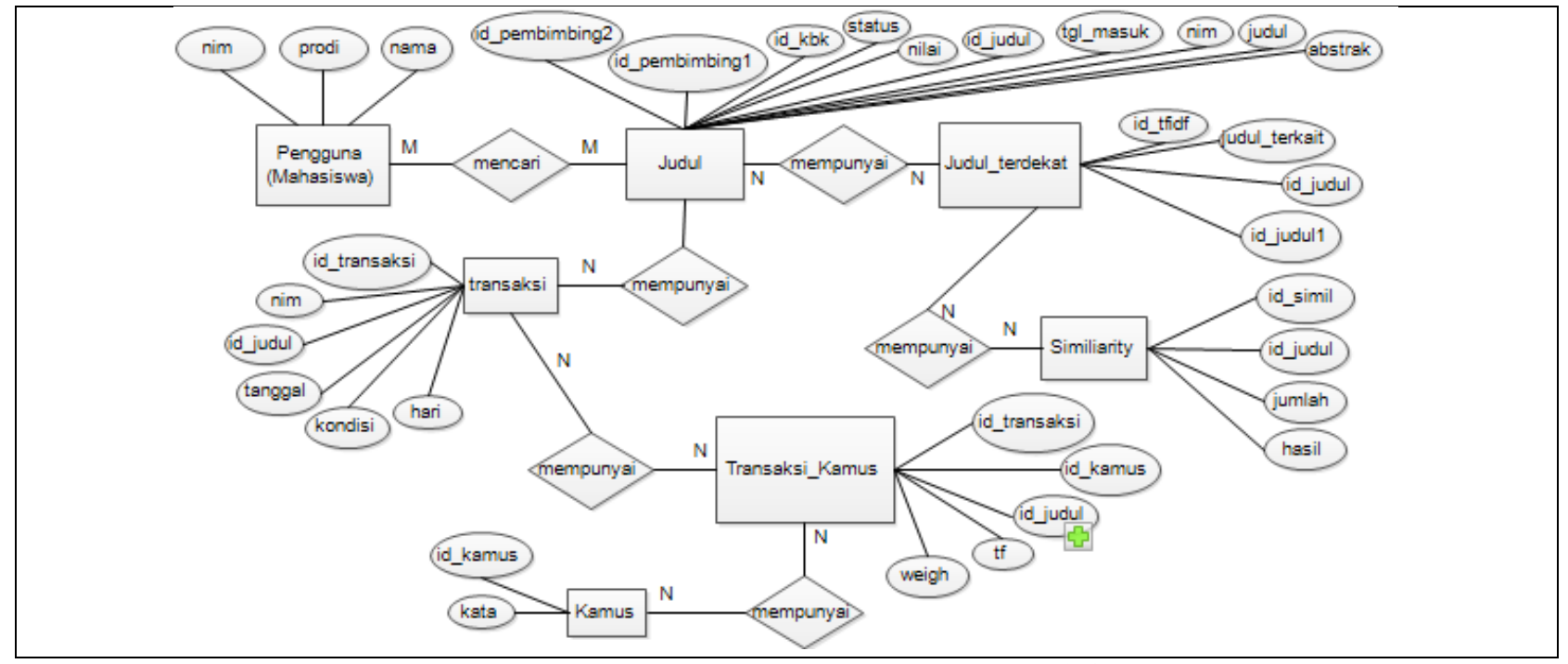

Gambar 5. ERD Fitur Mekanisme Pencarian Judul SISINTA 


\section{TEKNO Jumal Teknologi, Eektro, dan kejurvan}

http://journal2.um.ac.id/index.php/tekno | ISSN 1693-8739

Rancangan storyboard fitur mekanisme pencarian dengan metode term frequency dan invers document frequency (TF-IDF) pada sistem informasi skripsi dan tugas akhir (SISINTA) Jurusan Teknik Elektro Universitas Negeri Malang disajikan Gambar 6 dan Gambar 7 berikut.

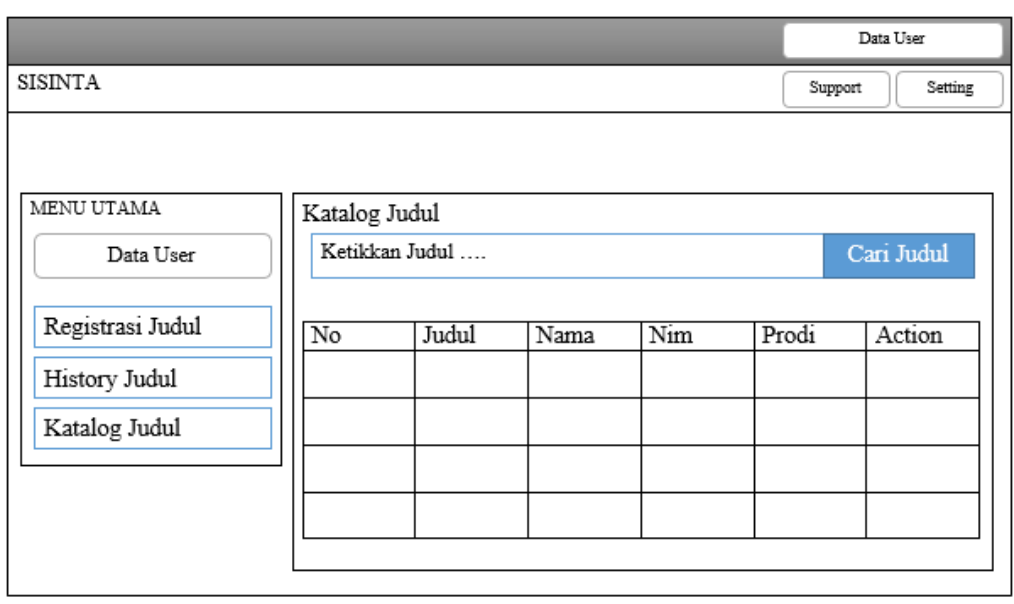

Gambar 6. Rancangan Storyboard Halaman Katalog Judul

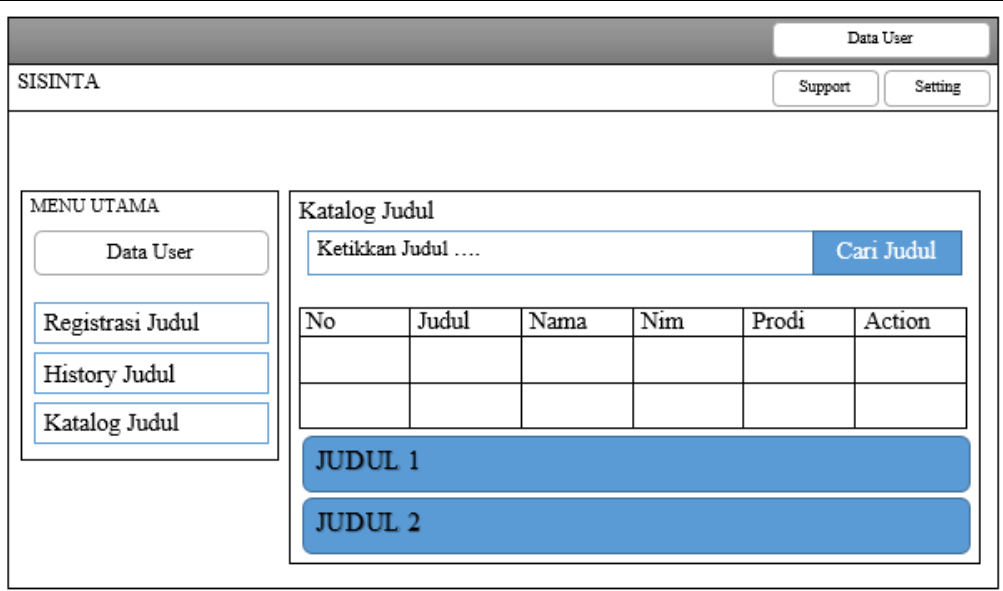

Gambar 7. Rancangan Storyboard Hasil Pencarian

3. Construction Of Prototype (Pembentukan Prototipe)

Tahap ini dilakukan dengan penggabungan elemen yang dirancang pada tahap perencanaan secara cepat. Seluruh elemen digabungkan sehingga membentuk suatu sistem yang lengkap. Elemen yang digabung meliputi; (1) desain antarmuka, (2) kode program, dan (3) basis data. Penggabungan dari semua elemen akan menghasilkan sistem yang siap untuk dijalankan dan dicoba oleh pengguna. 


\section{TEKNO Jumal Teknologi, Eektro, dan kejurvan}

http://journal2.um.ac.id/index.php/tekno | ISSN 1693-8739

\section{Deployment Delivery And Feedback (Penyerahan Dan Umpan Balik)}

Pada tahap penyerahan sistem dan umpan balik bertujuan untuk mendapatkan umpan balik, baik itu tanggapan berupa kritik maupun saran dari pengguna terhadap sistem yang dibangun. Pengguna dapat menguji sistem apakah sudah sesuai dengan spesifikasi kebutuhan yang diharapkan. Jika sistem belum memenuhi spesifikasi kebutuhan pengguna, maka akan dilakukan pengembangan prototype kedua. Proses pengembangan prototype akan terus berlanjut sampai sistem memenuhi spesifikasi kebutuhan pengguna.

\section{Hasil}

\section{Prototipe 1}

Halaman katalog judul berisi kumpulan judul mahasiswa yang telah melewati tahap penerimaan proposal judul skripsi. Fungsi halaman katalog judul adalah memberikan fitur pencarian judul-judul mahasiswa lain yang telah diterima. Tampilan halaman katalog judul disajikan pada Gambar 8.

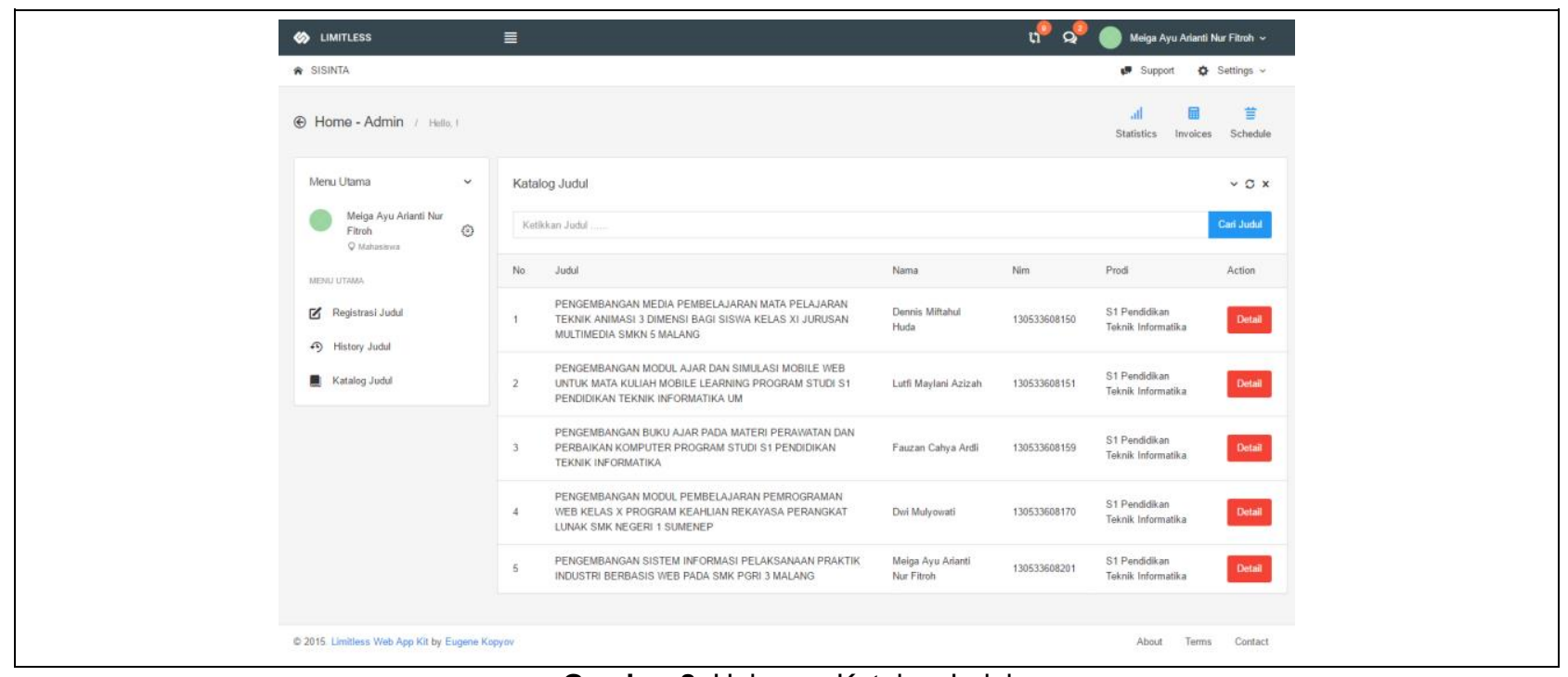

Gambar 8. Halaman Katalog Judul

Setelah masuk pada halaman katalog judul, pengguna dapat melihat daftar judul yang sudah diterima yang tersaji pada tabel yang berada di bawah kolom untuk melakukan pencarian. Pengguna yang ingin melakukan pencarian dapat memasukan kata kunci pencarian pada kolom yang tersedia. Tampilan kolom pencarian judul disajikan pada Gambar 9. 


\section{TEKNO Jumal Teknologi, Eektro, dan Kejuvran}

http://journal2.um.ac.id/index.php/tekno | ISSN 1693-8739

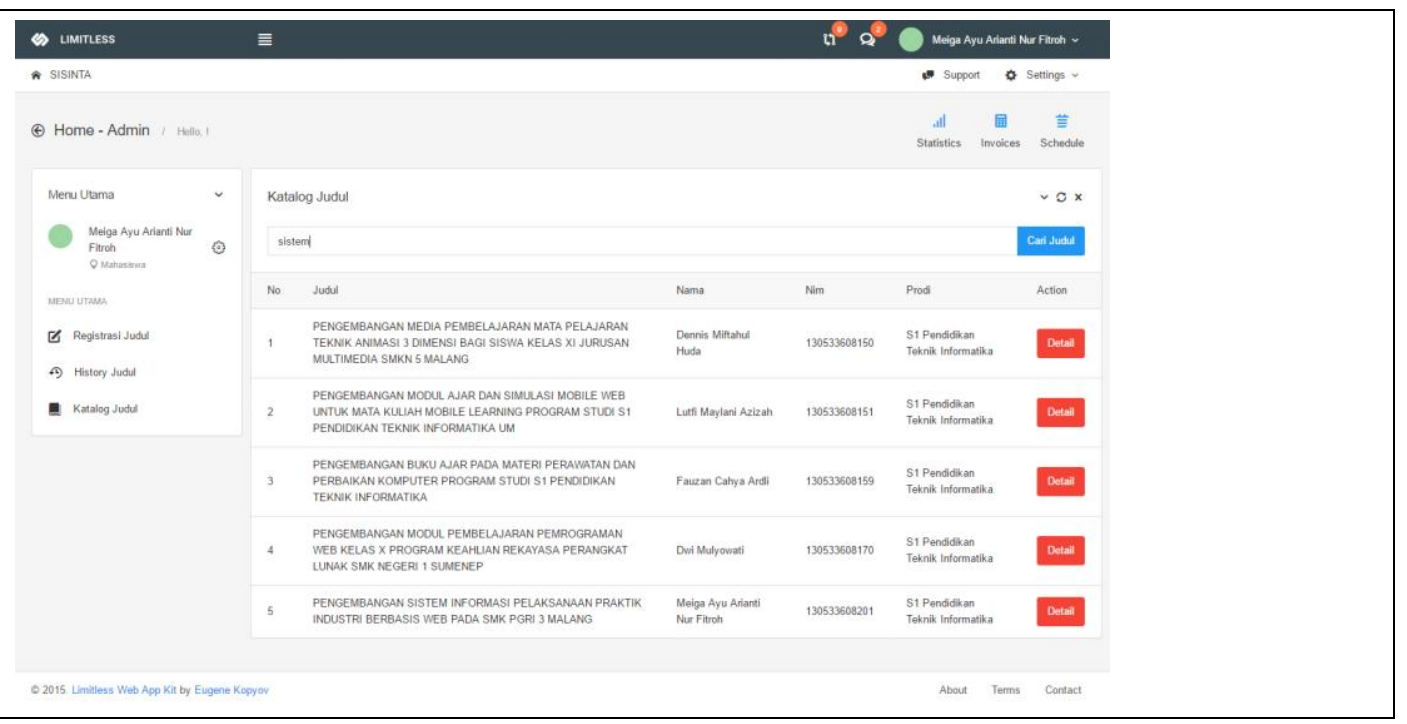

Gambar 9. Kolom Pencarian Judul

Setelah pengguna memasukan kata kunci pencarian, sistem akan menampilkan hasil pencarian judul yang terdekat sesuai dengan kata kunci. Hasil pencarian judul akan tersaji di bawah tabel judul skripsi yang telah diterima. Tampilan hasil pencarian tersaji pada Gambar 10 berikut.

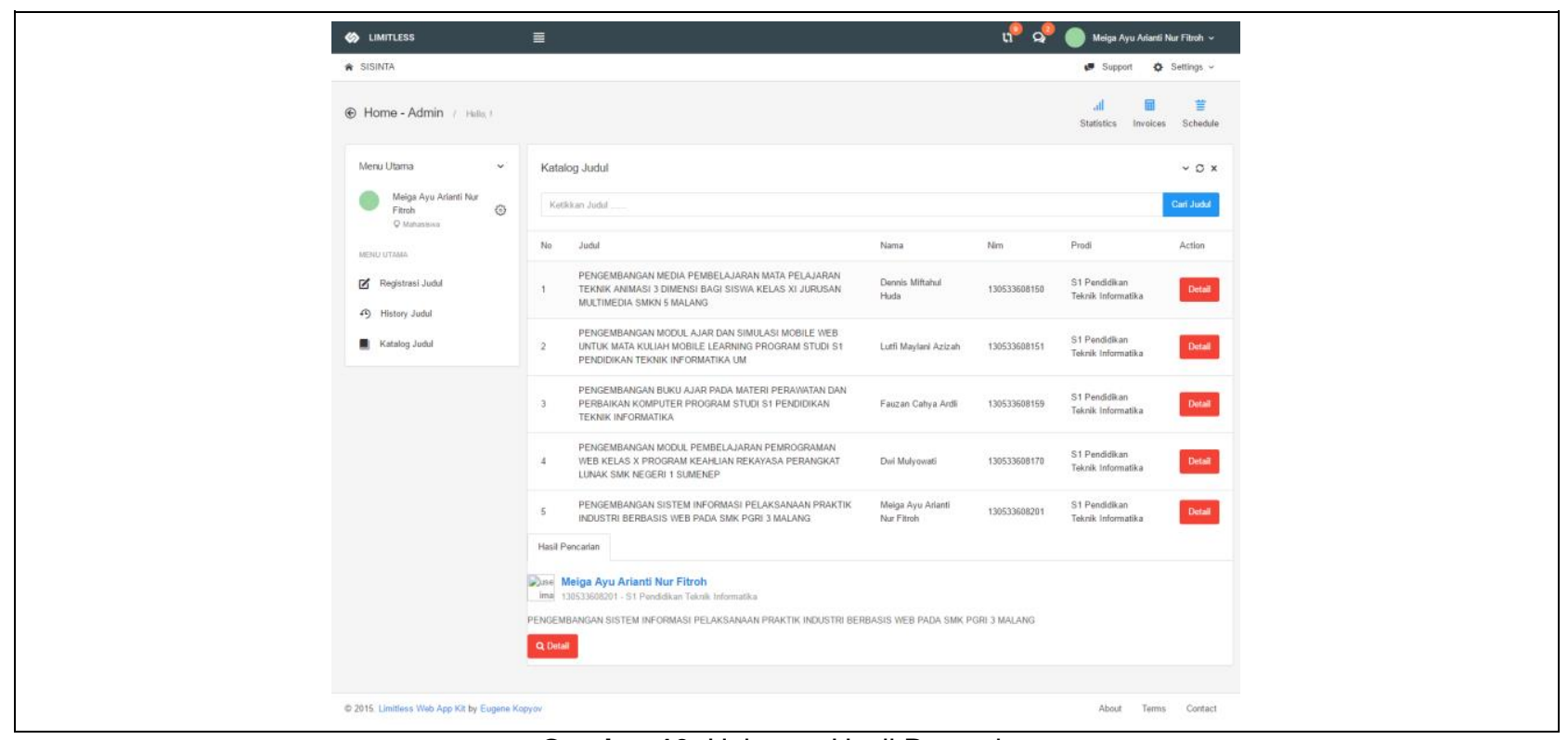

Gambar 10. Halaman Hasil Pencarian 


\section{TEKNO Jumal Teknologi, Eektro, dan kejurvan}

http://journal2.um.ac.id/index.php/tekno | ISSN 1693-8739

Selanjutnya dilakukan evaluasi oleh ahli sistem. Berdasarkan hasil evaluasi prototipe 1 masih diperlukan suatu siklus prototipe untuk membangun prototipe selanjutnya, karena pada prototipe 1 masih ditemukan beberapa kesalahan dan sistem masih belum berjalan dengan baik. Hasil evaluasi prototipe 1 dapat dilihat pada Tabel 1 berikut.

Tabel 1 Hasil Evaluasi Prototipe 1

\begin{tabular}{clll}
\hline No & Topik & \multicolumn{2}{c}{ Saran Revisi } \\
\hline 1 & Katalog Judul & - & Judul terbaru tidak perlu ditampilkan saat hasil pencarian muncul \\
& & - & Halaman pencarian cukup menampilkan 15 judul hasil pencarian \\
& & & pada halaman pertama \\
& & - & Perlu ditambahkan detail bobot tiap judul hasil pencarian \\
2 & Database & - & Jumlah dokumen judul pencarian ditambah \\
\hline
\end{tabular}

\section{Prototipe 2}

Tahapan prototipe 2 dibangun produk dengan mengikuti revisi sesuai dengan Tabel 1 . Halaman katalog judul diperbaiki sesuai dengan revisi prototipe 1. Tampilan halaman katalog judul pada prototipe 2 disajikan pada Gambar 11 berikut.

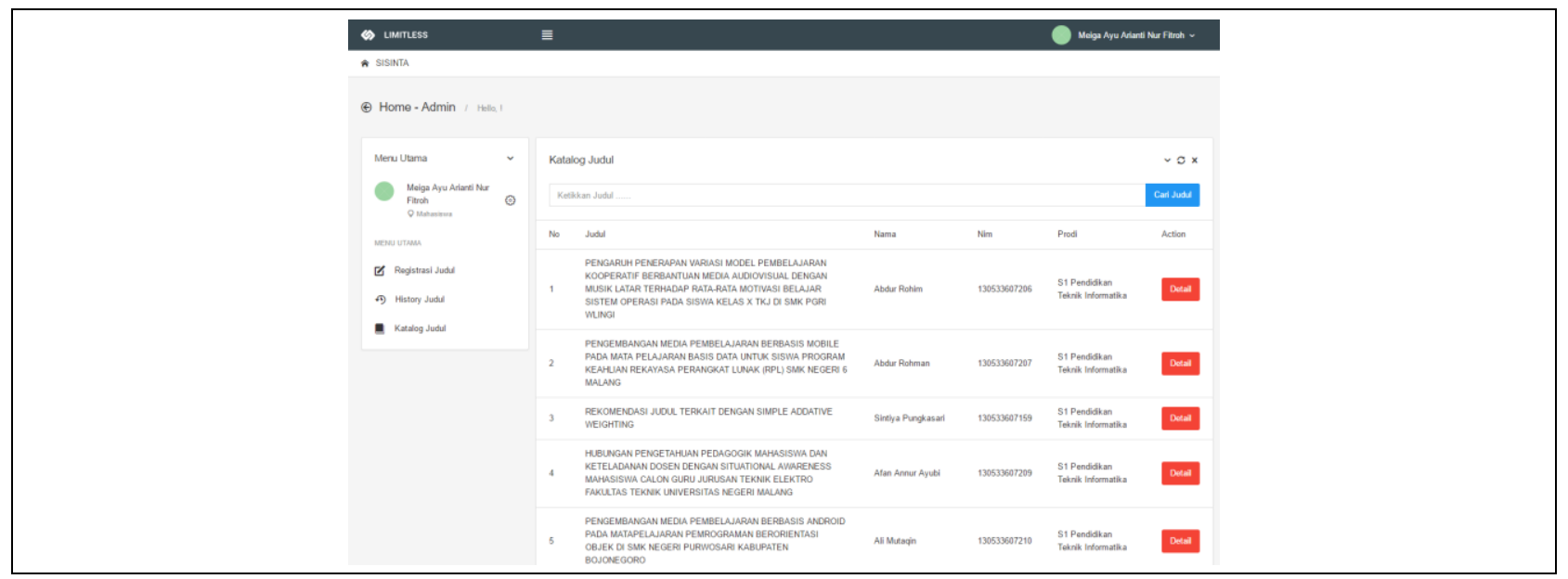

Gambar 11. Halaman Katalog Judul Prototipe 2

Tampilan hasil pencarian juga diperbaiki, sebelumnya hasil pencarian muncul di bawah tabel judul yang sudah diterima. Pada prototipe 2 hasil pencarian muncul di bawah kolom pencarian dan nilai bobot tiap judul juga ditampilkan. Hasil pencarian menampilkan 15 judul terdekat walaupun bobot judul tersebut 0 . Tampilan halaman hasil pencarian prototipe 2 disajikan pada Gambar 12 berikut. 


\section{TEKNO Jurnal Teknologi, Elektro, dan Kejuruan}

http://journal2.um.ac.id/index.php/tekno | ISSN 1693-8739



Gambar 12. Halaman Hasil Pencarian Prototipe 2

Setelah produk selesai dibangun, tahap selanjutnya adalah menyerahkan produk kepada ahli sistem untuk dievaluasi. Berdasarkan pengujian yang telah dilakukan, diperoleh data akhir sebesar $92 \%$ dari pengujian white-box dan $100 \%$ dari pengujian black-box. Hasil rata-rata uji coba dalam bentuk grafik ditunjukkan pada Gambar 13.

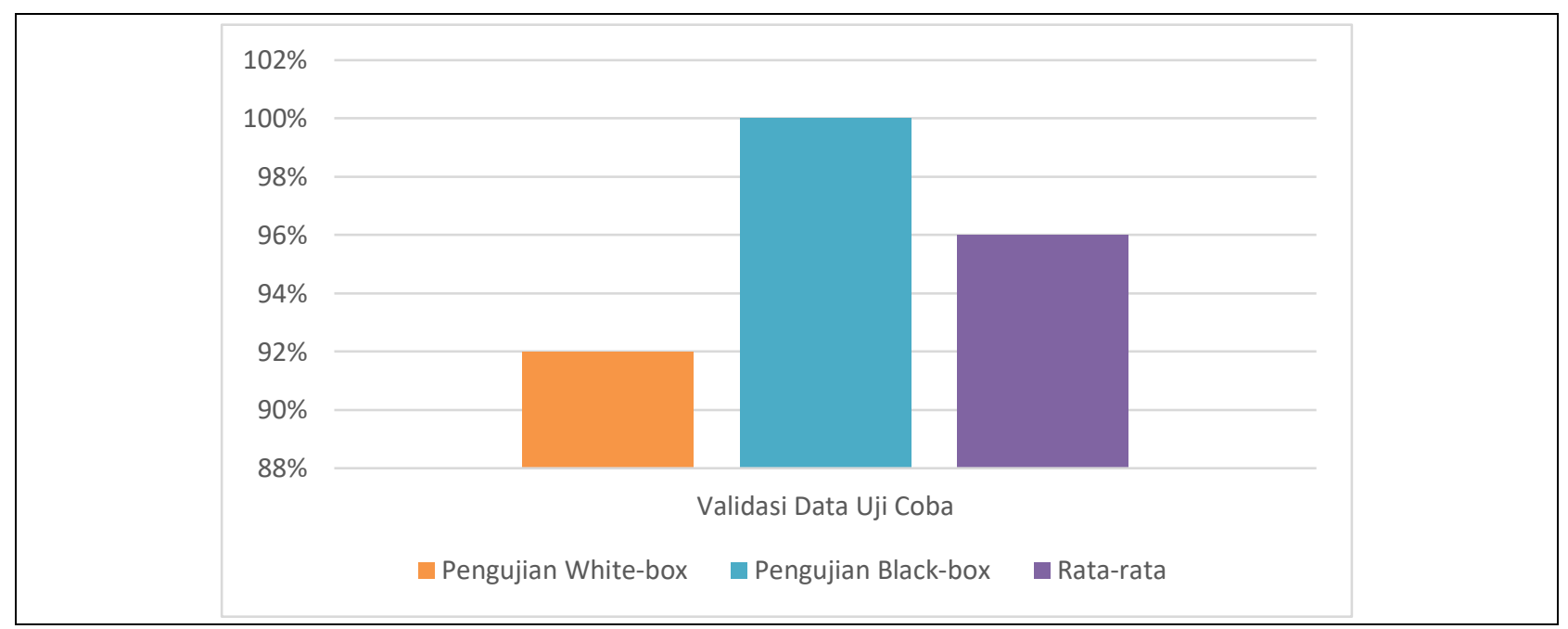

Gambar 13. Grafik Hasil Uji Coba 


\section{TEKNO Jurnal Teknologi, Elektro, dan Kejuruan}

http://journal2.um.ac.id/index.php/tekno | ISSN 1693-8739

Pada Gambar 13 tersaji hasil akhir uji coba. Pertama dari pengujian white-box yang dilakukan dengan pengujian akurasi, presisi, dan sensitifitas. Hasil pengujian menghasilkan rata rata persentase sebesar $92 \%$. Merujuk pada kajian pustaka dan penelitian terkait, perolehan rata-rata hasil pengujian sebesar 92\% menunjukkan penerapan metode TF-IDF pada mekanisme pencarian judul skripsi dapat menghasilkan hasil pencarian yang relevan dengan kata kunci pencarian. Hal ini dapat dilihat dari nilai akurasi, presisi, dan sensitifitas yang tinggi yang menunjukkan keakuratan, kecocokan dan kepekaan hasil pencarian sistem sangat baik(Simarmata, 2010).

Selanjutnya pada pengujian yang kedua yaitu pengujian black-box yang dilakukan dengan validasi ahli sistem. Pengujian black-box menguji fungsionalitas sistem berdasarkan faktor kualitas perangkat lunak pada ISO 9126 (Kristanto dkk, 2013 ). Hasil validasi menghasilkan persentase nilai $100 \%$ yang menunjukkan bahwa semua indikator validasi diterima oleh ahli sistem. Berdasarkan kajian pustaka pada sub-bab Teknik Pengujian dan Aspek Penilaian Perangkat Lunak serta hasil validasi sistem menunjukkan bahwa sistem telah menyediakan fungsi yang sesuai dengan yang diharapkan. Sistem telah memberikan keluaran yang sesuai dengan masukan, tampilan sistem telah tersaji sesuai dengan yang diharapkan dan tidak adanya eror yang ditemukan.

Berdasarkan grafik pada Gambar 13, maka sistem yang dikembangkan tergolong sangat valid dan sangat layak digunakan tanpa adanya revisi.

\section{Kesimpulan}

Berdasarkan kegiatan yang telah dilakukan di awal pengembangan, produk telah mampu memenuhi tujuan utama penelitian pengembangan sehingga dapat disimpulkan sebagai berikut: (1) Terbangun fitur katalog judul pada SISINTA yang telah dapat digunakan untuk melakukan pencarian judul skripsi dengan metode TF-IDF, (2) Kinerja metode TF-IDF telah diuji dengan pengujian white-box sesuai dengan metrik akurasi, presisi, dan sensitifitas dan menghasilkan rata-rata persentase hasil pengujian sistem sebesar $92 \%$, sehingga sistem yang dikembangkan termasuk dalam klasifikasi sempurna, dan (3) Pengujian fungsionalitas mekanisme pencarian dengan metode term frequency-invers document frequency (TF-IDF) telah dilakukan dengan pengujian black-box yang divalidasi oleh ahli sistem. Hasil rata-rata yang diperoleh adalah sebesar 100\%, sehingga dapat disimpulkan bahwa metode TF-IDF dalam mekanisme pencarian judul sangat valid dan dapat digunakan tanpa revisi.

\section{References}

Akbar, S. 2013. Instrumen Perangkat Pembelajaran. Bandung: PT. Remaja Rosdakarya. Al Fatta, H. 2007. Analisis dan Perancangan Sistem Informasi untuk Keunggulan Bersaing Perusahaan dan Organisasi Modern. Yogyakarta: Andi. 


\section{TEKNO Jurnal Teknologi, Elektro, dan Kejuruan}

http://journal2.um.ac.id/index.php/tekno | ISSN 1693-8739

Amin, F. 2011. Implementasi Search Engine (Mesin Pencari) Menggunakan Metode Vector Space Model. Jurnal IImiah Dinamika Teknik, V(1), 45-58. Fakultas Teknologi Informasi Universitas Stikubank Semarang, (Online), (https://www.unisbank.ac.id/ojs/index.php/ft1/article/view/1127/680), diakses 21 April 2017.

Ardiansah T. A., Wibawa A. J. \&Widiyaningtyas T. 2016. Penerapan Algoritma Start End Mid untuk Mendeteksi Kesalahan Logika Structured Query Language. Seminar Nasional Teknologi Informasi dan Multimedia, V(4), 1-6. Universitas AMIKOM Yogyakarta, (Online), (http://ojs.amikom.ac.id/ index.php/semnasteknomedia/article/view/1239/1177), diakses 5 Mei 2017.

Fauzi, M. A., Arifin, A. Z. \& Yuniarti, A. 2014. Term Weighting Berbasis Indeks Buku dan Kelas untuk Perangkingan Dokumen Berbahasa Arab. Jurnal Ilmiah Teknologi Informasi, 5(2), 435-442. Universitas Udayana, (Online), (https://ojs.unud.ac.id/index.php/lontar/article/view/16698/10989), diakses 22 April 2017. Jogiyanto. 2005. Analisis dan Desain Sistem Informasi. Yogyakarta: Andi.

Kristanto, FX Eko Budi. 2013. Kualitas Perangkat Lunak Model ISO 9126. (Online), (http://fxekobudi.net/ilmu-komputer/kualitas-perangkat-lunak-model-iso-9126/), diakses 1 Juli 2017.

Lancaster, F. W. 1979. Information Retrieval Systems: Characteristics, Testing, and Evaluation (2nd ed.). New York: John Wiley.

Mandala, R. \& Setiawan, H. 2002. Peningkatan Performansi Sistem Temu Kembali Informasi dengan Perluasan Query secara Otomatis. Bandung: Institut Teknologi Bandung.

Mutaqin, A. 2016. Peminatan Siswa SMA Menggunakan Metode Simple Additive Weighting. Skripsi tidak diterbitkan. Malang: PPs UM.

Nasution, M.N. 2001. Manajemen Mutu Terpadu. Jakarta: Ghalia Indonesia.

Nurdiana, Ogie, Jumadi \& Nursantika, Dian. 2016. Perbandingan Metode Cosine Similarity Dengan Metode Jaccard Similarity Pada Aplikasi Pencarian Terjemah AI-Qur'an Dalam Bahasa Indonesia. JOIN (Jurnal Online Informatika), Vol 1, No 1. UIN Sunan Gunung Djati Bandung, (Online), (http://join.if.uinsgd.ac.id/joinbeta/index.php/join/article/view/12), diakses 1 Agustus 2017.

Nurjannah M., Hamdani \& Astuti, I. F. 2013. Penerapan Algoritma Term Frequency-Inverse Document Frequency (TF-IDF) Untuk Text Mining. Jurnal Informatika Mulawarman, Vol 8, No 3. Universitas Mulawarman, (Online), (http://ejournals.unmul.ac.id/index.php/JIM/article/view/113), diakses 1 Agustus 2017. Pendit, P. L. 2008. Perpustakaan Digital dari A sampai Z. Jakarta: Cita Karya Karsa Mandiri. Powers, D. M. W. 2011. Evaluation: from Precision, Recall and F-measure to ROC, Informedness, Markedness and Correlation. Journal of Machine Learning Technologies, 2(1), 37-63. Flinders University, (Online), (http://dspace2. flinders.edu.au/xmlui/bitstream/handle/2328/27165/Powers\%20Evaluation.pdf?sequence=1) , diakses 10 April 2017. 


\section{TEKNO Jurnal Teknologi, Elektro, dan Kejuruan}

http://journal2.um.ac.id/index.php/tekno | ISSN 1693-8739

Pressman, R. S. 2002. Rekayasa Perangkat Lunak Pendekatan Praktisi (Buku Satu). Yogyakarta: Andi.

Pressman, R. S. 2010. Software Engineering: A Practitioner's Approach. New York: McGrawHill.

Pressman, R. S. 2012. Rekayasa Perangkat Lunak (Pendekatan Praktisi) Edisi 7: Buku 1. Yogyakarta: Andi.

Pujianto, U. 2013. Using Cosine Similarity For Determining The Inversed Document Frequency Value of Newly Added Documents. Seminar on Electrical Informatics and ITS Education. (Online), (http://elektro.um.ac.id/ ceie/2013/download_pdf/if/31.pdf), diakses 22 Mei 2017.

Pusat Bahasa Depdiknas. 2002. Kamus Besar Bahasa Indonesia (Ketiga). Jakarta: Balai Pustaka.

Simarmata, Janner. 2010. Rekayasa Perangkat Lunak. Yogyakarta. Andi Publisher.

Saadah, M. N., Atmagi, R. W., Rahayu, D. S. \& Arifin, A. Z. 2013. Sistem Temu Kembali Dokumen Teks dengan Pembobotan Tf-Idf Dan LCS. Jurnal IImiah Teknologi Informasi (JUTI), 11(1), 17-20. Institut Teknologi Sepuluh November Surabaya, (Online), (https://doi.org/10.12962/ j24068535.v11i1.a16), diakses 20 Mei 2017.

Satria, R. 2015. Integrasi Bagging dan Greedy Forward Selection pada Prediksi Cacat Software dengan Menggunakan Naïve Bayes. Jurnal of Software Engineering, 1(2), 101-108. (Online), (http://journal.ilmukomputer.org/ index.php/jse/article/view/69/36), diakses 25 Mei 2017.

Schniter, P. 2003. Vector Space, 1-2. (Online), (https://www.google.com/ url?sa=t\&rct=j\&q=\&esrc=s\&source=web\&cd=1\&cad=rja\&uact=8\&ved=0ahUKEwjL_73Cg7X VAhXFq48KHQqMDZEQFggoMAA\&url=http\%3A\%2F\%2Fwww.ucccs.info\%2Fucc\%2Fucc4 \%2Fucc2014\%2F2014\%2520Study\%2FCS4611\%2FSlides\%2FL6_SCORINGEXAMPLE\%2520\%5B\% 2520Most\%2520important\%2520part\%2520of\%2520Vector\%2520Space\%2520Model\%252 0Exercise\%2520\%5D.pdf\&usg=AFQjCNGc0joU0RRkbcjjwqxIK1S-YJlrxQ), diakses 20 Januari 2017.

Wahono, R. S. 2006. Teknik Pengukuran Kualitas Perangkat Lunak, (Online), (http://romisatriawahono.net/2006/06/05/teknik-pengukuran-kualitas-perangkat-lunak/), diakses 1 Juli 2017.

Waspodo, D. H. R. 2015. Integrasi Sistem Informasi Skripsi Dengan Logbook Skripsi pada Jurusan Teknik Elektro UM. Skripsi tidak diterbitkan. Malang: PPs UM.

Zafikri, A. 2008. Implementasi Metode Term Frequency Inverse Document Frequency (Tf-Idf) pada Sistem Temu Kembali Informasi. Universitas Sumatera Utara, (Online), (http://repository.usu.ac.id/handle/123456789/ 16465), diakses 21 Mei 2017. 